\title{
The Effect of the Ministry of Health's Periodic Free Drug Policy on Smoking Cessation Polyclinic
}

\author{
Sağlık Bakanlığının Dönemsel Ücretsiz İlaç Politikasının Sigara Bırakma Polikliniğine Olan Etkisi
}

\author{
Şerif KURTULUŞ ${ }^{1}$ \\ (i) 0000-0002-1082-3700 \\ Remziye CAN ${ }^{2}$ \\ (D) 0000-0001-5913-6007 \\ Zafer Hasan Ali SAK ${ }^{1}$ \\ (D) 0000-0002-2388-2259
}

\begin{abstract}
${ }^{1}$ Harran University Medical Faculty Department of Chest Diseases, Sanliurfa, Turkey

${ }^{2}$ Mustafa Kemal Atatürk Vocational and Technical Anatolian High School, Eskişehir, Turkey
\end{abstract}

\begin{abstract}
Aim: The aim of this study is to evaluate the effect of periodic free drug applications of the Ministry of Health on Smoking Cessation Polyclinic (SCP) and the success rates of the treatment methods used.

Material and Methods: A total of 1861 patients applied to SCP in a county state hospital in Şanlıurfa between January 1 and December 31, 2017 were included in this study. Patients not smoke for at least six months were accepted as non-smokers. Each patient was followed up for at least six months. The data was calculated as number and percentage.

Results: According to months the highest application was seen in December. In July and November, there was a significant decrease in the number of patients applying to SCP. It was determined that $80.0 \%$ of the patients received behavior therapy, $20.0 \%$ received pharmacological treatment. Utilization of pharmacological treatment was the lowest in July with no patient and the highest in November with $96.8 \%$. The rate of quitting with pharmacological treatment was $27.4 \%$ while this rate was $18.9 \%$ with behavioral therapy.

Conclusion: The Ministry of Health's periodic free drug application policy has a direct impact on SCPs. This may be the reason for resistance in patients to smoking cessation with behavioral therapy. Smoking cessation treatments should be provided throughout the year. It is recommended that free drug treatments include all drugs and supply from pharmacies through report. We think that with these arrangements, the compliance of patients to treatment and their determination to quit smoking will increase.

Keywords: Behavior therapy; health policy; pharmacotherapy; smoking; smoking cessation
\end{abstract}

ÖZ

Amaç: Bu çalışmanın amacı Sağlık Bakanlığı'nın dönemsel ücretsiz ilaç uygulamalarının Sigara Bırakma Polikliniği (SBP)'ne olan etkisi ve kullanılan tedavi yöntemlerinin başarı oranlarının değerlendirilmesidir.

Gereç ve Yöntemler: Bu çalışmaya 1 Ocak ve 31 Aralık 2017 tarihleri arasında Şanlıurfa'da bulunan bir ilçe devlet hastanesinde SBP'ye başvuran toplam 1861 hasta dahil edildi. En az altı ay boyunca sigara içmeyen hastalar sigarayı bırakmış olarak kabul edildi. Her hastanın en az altı ay süreyle takibi yapıldı. Elde edilen veriler sayı ve yüzde olarak hesaplandı.

Bulgular: Aylara göre en yüksek başvurunun Aralık ayında olduğu görüldü. Temmuz ve Kasım aylarında ise SBP'ye başvuran hasta sayılarında belirgin bir düşme vardı. Hastaların $\% 80,0$ 'inin davranış terapisi aldığı, \%20,0'sinin ise farmakolojik tedavi aldığı tespit edildi. Farmakolojik tedavi uygulaması en düşük hiç hastanın olmadığı Temmuz ayında ve en yüksek ise \%96,8 ile Kasım ayında idi. Farmakolojik tedavi ile bırakma oranı \%27,4 iken davranış terapisi ile burakma oranı ise \%18,9 idi.

Sonuç: Sağlık Bakanlığı'nın dönemsel ücretsiz ilaç uygulama politikası SBP'yi direkt olarak etkilemektedir. Bu durum, hastalarda davranış terapisi ile sigara bırakmaya karşı bir direnç nedeni olabilmektedir. Sigara bırakma tedavilerinin yıl boyu karşılanması gereklidir. Ücretsiz ilaç tedavilerinin tüm ilaçları kapsaması ve rapor karşılı̆̆ eczanelerden temini yoluna gidilmesi önerilir. $\mathrm{Bu}$ düzenlemeler ile hastaların tedaviye uyumu ve sigara bırakma kararlılığının artacağını düşünmekteyiz.

Received / Geliş Tarihi : 06.12.2019

Accepted / Kabul Tarihi : 09.03.2020 Available Online /

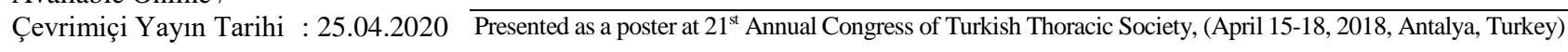

Şerif KURTULUŞ

drkurtulus1@gmail.com

\section{Sorumlu Yazar}

\section{birakma}




\section{INTRODUCTION}

Smoking is an important public health problem, and there has been no sign of improvement. It results in social and economic harm, is responsible for numerous diseases, and decreased quality of life. Cigarette addiction treatment is important for public health, preventive medicine, and chest diseases $(1,2)$. Even simply explaining the harms of smoking and recommending a patient to quit may increase the likelihood of smoking cessation (3). With respect to cessation therapies, behavioral training and pharmacotherapy are two proven approaches to therapeutic support $(3,4)$. The aim of this study was to evaluate the application of The Ministry of Health's periodic free drug delivery policy, the methods and success rates of treatments used in Smoking Cessation Polyclinic (SCP).

\section{MATERIAL AND METHODS}

This is a retrospective registry-scan design study performed between January 1, 2017 and December 31, 2017. A total of 1861 patients who had applied to the SCP of Şanlıurfa Ceylanpınar County State Hospital were included in the study. Quarterly reports of 1861 patients admitted to the SCP were evaluated. Drug therapy and behavior training were recorded in terms of supportive therapy. The data were organized as quarterly reports requested by the Ministry of Health. Persons who did not smoke for at least six months were considered as nonsmoker who quit smoking. For this reason, regardless of which month they applied, patients were followed up for at least six months. This study was approved by the Harran University Ethical Committee (01.02.2018; session: 02; decision no: 08).

\section{Statistical Analysis}

Descriptive statistics of the data were calculated as numbers and percentages in quarterly periods for each treatment method.

\section{RESULTS}

Of the 1861 patients admitted to the SCP, 1489 (80.0\%) were received behavior therapy and $372(20.0 \%)$ were received pharmacological treatment (Table 1). When the distribution of treatment modalities by months was examined, it was observed that the lowest number of pharmacological treatment was in July with no patient and the highest number was in November with 60 (96.8\%) applicants. Behavior therapy was at its lowest in November with $2(3.2 \%)$ patients and highest in July with $34(100 \%)$ patients (Table 1).

When the smoking cessation status of the patients admitted to the SCP was examined according to treatment methods, $102(27.4 \%)$ of the 372 patients received pharmacological treatment were shown to have quit smoking since three months while $102(27.4 \%)$ patients had not quit smoking, and there were 168 (45.2\%) patients with unknown status (Table 2).

When the smoking cessation status of the patients who had applied to the SCP and received behavioral therapy was examined, of the total 1489 patients, $282(\% 18.9)$ had quit smoking while $672(45.1 \%)$ of them continued to smoke. The number of patients with unknown status was $535(35.9 \%)$ among patients who had received behavioral therapy (Table 3).
Table 1. Monthly distribution of treatment modalities of patients admitted to smoking cessation polyclinic, $\mathrm{n}(\%)$

\begin{tabular}{lccc}
\hline January & $\begin{array}{c}\text { Pharmacological } \\
\text { Treatment }\end{array}$ & $\begin{array}{c}\text { Behavior } \\
\text { Therapy }\end{array}$ & Total \\
February & $4(0.8)$ & $130(99.2)$ & 131 \\
March & $11(6.5)$ & $125(96.9)$ & 129 \\
April & $21(15.8)$ & $112(84.2)$ & 133 \\
May & $20(13.8)$ & $125(86.2)$ & 145 \\
June & $32(22.7)$ & $109(77.3)$ & 141 \\
July & $0(0.0)$ & $34(100)$ & 34 \\
August & $51(20.1)$ & $203(79.9)$ & 254 \\
September & $45(35.4)$ & $82(64.6)$ & 127 \\
October & $42(29.8)$ & $99(70.2)$ & 141 \\
November & $60(96.8)$ & $2(3.2)$ & 62 \\
December & $85(21.5)$ & $311(78.5)$ & 396 \\
\hline Total & $372(20.0)$ & $1489(80.0)$ & 1861 \\
\hline
\end{tabular}

Table 2. Three monthly smoking cessation status of patients receiving pharmacological treatment, $\mathrm{n}(\%)$

\begin{tabular}{lcccc}
\hline & Stopped & Not stopped & Unknown & Total \\
\hline Jan-Mar & $12(75.0)$ & $4(25.0)$ & $0(0.0)$ & 16 \\
Apr-Jun & $25(34.2)$ & $10(13.7)$ & $38(52.1)$ & 73 \\
Jul-Sep & $20(20.8)$ & $46(47.9)$ & $30(31.3)$ & 96 \\
Oct-Dec & $45(24.1)$ & $42(22.5)$ & $100(53.5)$ & 187 \\
\hline Total & $102(27.4)$ & $102(27.4)$ & $168(45.2)$ & 372 \\
\hline
\end{tabular}

Jan-Mar: January to March, Apr-Jun: April to June, Jul-Sep: July to September, Oct-Dec: October to December

Table 3. Three monthly smoking cessation of patients receiving behavior therapy, $\mathrm{n}(\%)$

\begin{tabular}{lcccc}
\hline & Stopped & Not stopped & Unknown & Total \\
\hline Jan-Mar & $88(21.4)$ & $274(66.5)$ & $50(12.1)$ & 412 \\
Apr-Jun & $87(25.1)$ & $80(23.1)$ & $179(51.7)$ & 346 \\
Jul-Sep & $32(10.0)$ & $167(52.4)$ & $120(37.6)$ & 319 \\
Oct-Dec & $75(18.2)$ & $151(36.7)$ & $186(45.1)$ & 412 \\
\hline Total & $282(18.9)$ & $672(45.1)$ & $535(35.9)$ & 1489
\end{tabular}

Jan-Mar: January to March, Apr-Jun: April to June, Jul-Sep: July to September, Oct-Dec: October to December

\section{DISCUSSION}

In our study, the number of patients who applied to the SCP in one year was 1861. Behavior therapy was not conducted in November, while pharmacological treatment was highest at $96.8 \%$. In July, no patient was given pharmacological treatment. The rate of patients receiving behavior therapy was $80.0 \%$ and pharmacological treatment was $20.0 \%$. With respect to pharmacological treatment, it was found that $27.4 \%$ had stopped smoking, $27.4 \%$ had not quit and their status was unknown in the $45.2 \%$ of patients. With regard to behavior therapy, $18.9 \%$ 
had quit, $45.1 \%$ had not and no determination could be made for $35.9 \%$ of the patients.

At the end of one year, smoking cessation success rates were found to be $30 \%$ in a study by Bakkevic et al. (5), $37.4 \%$ in a study by Yaşar et al. (6), and $27.9 \%$ in a study by Çelik et al. (7). Our study showed lower smoking cessation rates at the end of three months compared these studies.

While there is one smoking cessation outpatient clinic in South Africa (8), the number in Turkey was 25 in 2002 and had exceeded to 400 in recent years (1). The extensive healthcare service provided at these outpatient clinics includes the distribution of some 300000 pharmacotherapy drugs free of charge - as such, it is important that these resources are used efficiently within the context of public health strategies (9). In our hospital, smoking cessation counseling was provided to 1861 patients at the SCP. Our relatively low smoking cessation rates might be explained by some factors related both subjects and SCPs. P1çakçıefe et al. (10) reported that the most frequent applications to the SCP were in the spring. In our study, the highest number of applications was in the December. The high level of pharmacological treatment in November and the exceptionally high level of admissions to the SCP in December coincided with the Ministry of Health's free distribution of smoking cessation drugs. The refusal of behavior therapies by these patients can only be explained by their requests for pharmacological treatment.

As pharmacotherapy is expensive and was provided by free of charge by the Ministry of Health, there is evidence to suggest that patients have attempting to secure the drug in advance for later use (11).

In their study, Berkeşoğlu et al. (12) found that the success rate for quitting was $30.9 \%$ among those receiving free medication provided by the Ministry of Health, while the success rate for treatment in the paid group was $18 \%$. Similar studies reported no difference in smoking cessation rates between those in receipt of paid/free medication $(13,14)$.

In the most comprehensive study involving smoking cessation medications in China, $43 \%$ of the patients received pharmacotherapy (15). In our study, only $20.0 \%$ of patients received pharmacotherapy.

In the literature, the combination of pharmacotherapy and behavior education treatment resulted in a one-year cessation rate of $52.3 \%$, and a rate of $14.0 \%$ for behavior therapy alone (12). In our study, the combination of pharmacotherapy and behavior therapy resulted in a cessation rate of $27.4 \%$, whereas $18.9 \%$ of the patients who received only behavior therapy were successful in stopping smoking.

It has been shown that with respect to smoking cessation rates, that encouraging patients to stop has a better outcome than making no recommendations at all (16). A high level of patient compliance has also been shown to be effective in the patient's successfully stopping smoking (17-19). Although there is evidence to suggest that encouraging patients to stop smoking (by issuing coupons, paying cash, and giving gifts) results in an improvement in both short and long term success rates, debates continue on this matter (20). Encouraging the patient as well as his or her physician are other issues discussed in relation to these processes (21).
Most smokers perceive deterioration in their quality of life over time (11). They then try to quit smoking to halt this downward trend, however, most of these efforts fail (22). Smoking cessation will be more effective if such patients know that professional support is available and that pharmacotherapy support will be provided when necessary (23).

A number of findings in our study about SCP have been reported previously in the literature. These are:

- The Ministry of Health's periodic unpaid drug delivery policy is applied in a different city, different month in the year;

- Some of the smoking cessation drugs are not in stock while some are also plentiful.

- Admissions for the use of drugs in the months when they are declared to be free of charge or to take drugs for later use indirectly leads to rejection of behavior therapy;

- If the SCP is the only program in the health center, the performance of the attending physician will vary from month to month, as such, the motivation of follow-up of patients or of those who have been recently admitted to the program may decrease.

- Lack of regular follow-up of patients and insufficient supportive treatment may lead to resistance and hopelessness, such as the idea that patients will not be able to quit smoking despite the use of behavior or pharmacotherapy.

- Monitoring of the use of smoking cessation drugs, addressing possible questions, and eliminating problems will increase compliance and stability of treatment.

As a result, a behavior therapy in patients who want to quit smoking is important. In addition to behavior support, pharmacotherapy may positively affect treatment success. The periodic free drug delivery policy of the Health Ministry directly affects the SCP and may result in resistance on the part of patients to behavior therapies. Like other medicines used in the treatment of chronic diseases, smoking cessation treatments should be supplied year-round by pharmacies on the production of a report. In addition, in order to follow-up the patient and increase the success of cessation treatments, the drugs should be supplied in packages of 2 -weeks duration. We think that with these arrangements, the compliance of patients to treatment and their determination to quit smoking will increase.

\section{REFERENCES}

1. Uzaslan EK. Sigarayı bırakma yöntemleri. Özyardımcı EN, editör. Sigara ve sağlık. Bursa: 2002. s.441-66.

2. Çan G, Öztuna F, Özlü T. The evaluation of outpatient smoking cessation clinic results of Karadeniz Technical University. Tuber Toraks. 2004;52(1):69-74.

3. Fiore MC, Bailey WC, Cohen SJ, Dorfman S, Goldstein M, Gritz ER, et al. Treating tobacco use and dependence. Rockville (MD): US Department of Health and Human Service; 2000.

4. West R, McNeill A, Raw M. Smoking cessation guidelines for health professionals: an update. Health Education Authority. Thorax. 2000;55(12):987-99. 
5. Bakkevig O, Steine S, von Hafenbrädl K, Laerum E. Smoking cessation. A comparative, randomised study between management in general practice and the behavioural programme SmokEnders. Scand J Prim Health Care. 2000;18(4):247-51.

6. Yaşar Z, Kar Kurt Ö, Talay F, Kargı A. One-year follow up results of smoking cessation outpatient clinic: Factors affecting the cessation of smoking. Eurasian J Pulmonol. 2014;16(2):99-104

7. Çelik İ, Yüce D, Hayran M, Erman M, Kılıçkap S, Buzgan $\mathrm{T}$, et al. Nationwide smoking cessation treatment support program--Turkey project. Health Policy. 2015;119(1):50-6.

8. Tadzimirwa GY, Day C, Esmail A, Cooper C, Kamkuemah M, Dheda K, et al. Challenges for dedicated smoking cessation services in developing countries. S Afr Med J. 2019;109(6):431-6.

9. Elbek O, Kılınç O, Aytemur ZA, Akyıldız L, Uyanusta Küçük Ç, Özge C, et al. Tobacco control in Turkey. Turk Thorac J. 2015;16(3):141-50.

10. P1çakçıefe M, Akkaya V, Erbaş E, Doğu B. Evaluation of the referrals to the smoking cessation polyclinic betwen 2015-2016 in Muğla. Nobel Med. 2019;15(1):21-7.

11. Karadoğan D, Önal Ö, Şahin DS, Kanbay Y, Alp S, Şahin Ü. Treatment adherence and short-term outcomes of smoking cessation outpatient clinic patients. Tob Induc Dis. 2018;16:38.

12. Berkeşoğlu Ç, Özgür ES, Demir AU. Factors affecting the success of smoking cessation. Mersin Univ Saglık Bilim Derg. 2018;11(3):355-65.

13. Kanatsız B, Başlılar Ş, Şaylan B, Albay A, Uçak Basat S. Evaluation of the factors affecting success rate and medical treatments in smoking cessation. Euras J Fam Med. 2017;6(2):65-71.

14. Fai SC, Yen GK, Malik N. Quit rates at 6 months in a pharmacist-led smoking cessation service in Malaysia. Can Pharm J (Ott). 2016;149(5):303-12.
15. Lin H, Xiao D, Liu Z, Shi Q, Hajek P, Wang C. National survey of smoking cessation provision in China. Tob Induc Dis. 2019;17:25.

16. Slama K, Redman S, Perkins J, Reid ALA, SansonFisher RW. The effectiveness of two smoking cessation programmes for use in general practice: A randomized clinical trial. BMJ. 1990;300(6741):17079.

17. Fidan F, Pala E, Ünlü M, Sezer M, Kara Z. Factors affecting smoking cessation and success rates of the treatment methods used. Kocatepe Med J. 2005;6(3):27-34.

18. Hays JT, Leischow SJ, Lawrence D, Lee TC. Adherence to treatment for tobacco dependence: association with smoking abstinence and predictors of adherence. Nicotine Tob Res. 2010;12(6):574-81.

19. Balmford J, Borland R, Hammond D, Cummings KM. Adherence to and reasons for premature discontinuation from stop-smoking medications: data from the ITC Four-Country Survey. Nicotine Tob Res. 2011;13(2):94-102.

20. Notley C, Gentry S, Livingstone-Banks J, Bauld L, Perera R, Hartmann-Boyce J. Incentives for smoking cessation. Cochrane Database Syst Rev. 2019;7:CD004307.

21. Milcarz K, Polańska K, Balwicki Ł, MakowiecDąbrowska T, Hanke W, Bąk-Romaniszyn L, et al. Perceived barriers and motivators to smoking cessation among socially-disadvantaged populations in Poland. Int J Occup Med Environ Health. 2019;32(3):363-77.

22. El-Khoury Lesueur F, Bolze C, Melchior M. Factors associated with successful vs. unsuccessful smoking cessation: Data from a nationally representative study. Addict Behav. 2018;80:110-5.

23. Zhu S, Melcer T, Sun J, Rosbrook B, Pierce JP. Smoking cessation with and without assistance: a population-based analysis. Am J Prev Med. 2000;18(4):305-11. 